\title{
Thyrotoxicosis induced by iodine contamination of food- a common unrecognised condition?
}

\author{
J C STEWART, G I VIDOR
}

British Medical fournal, 1976, 1, 372-375

\section{Summary}

The incidence of thyrotoxicosis in northern Tasmania rose significantly in 1964, two years before an epidemic of iodine-induced thyrotoxicosis was precipitated by the addition of iodate to bread to prevent goitre. Each time older patients accounted for most of the increase. The 1964 increase was probably iodine-induced as the use of iodophor disinfectants on dairy farms, which causes iodine residues in milk, began in 1963 and a fall in the prevalence of goitre in young children suggested an increase in dietary iodine at about that time. A further small increase in thyrotoxicosis in 1971 may also have been iodine-induced as it followed an extension of the use of iodophors.

Dietary iodine is rising substantially in many places because of high iodine levels in milk and the use of iodine compounds in automated bread making, and this may be causing unsuspected iodine-induced thyrotoxicosis. Dietary iodine should be monitored regularly and clinicians alerted to any rise. Contamination of common foods with iodine should be more strictly controlled.

\section{Introduction}

All iodine-induced thyrotoxicosis reported so far has been iatrogenic. It has been described when large doses of iodine have been given to treat goitre, ${ }^{1-5}$ during iodine repletion tests, ${ }^{6}$ in clinical research, ${ }^{78}$ and when iodine has been used to block thyroid uptake of radioiodine in the ${ }^{125}$ I-fibrinogen test. ${ }^{9}$ In epidemic form it has been reported in areas where goitre is endemic when iodine supplementation has been introduced for goitre prophylaxis, in either salt ${ }^{10}{ }^{11}$ or bread. ${ }^{12} 13$

Our studies of the epidemic that occurred in Tasmania after iodate was added to bread in 1966 showed what had passed unnoticed at the time: that the incidence of thyrotoxicosis in northern Tasmania increased in 1964, two years before bread iodination.

Although we know of no report of iodine-induced thyrotoxicosis having occurred in response to chance increases in dietary iodine, it would be strange if this had never happened. To explore the possibility of its having occurred in northern Tasmania in 1964 we obtained further information on the incidence of thyrotoxicosis and related this to possible changes in iodine nutrition.

\section{Patients and methods}

The incidence of thyrotoxicosis from 1960 to 74 was measured by studying two groups: group 1 consisted of all thyrotoxic patients seen at Launceston General Hospital, however treated; group 2 consisted of thyrotoxic patients treated elsewhere in northern Tasmania by partial thyroidectomy or ${ }^{131}$ I treatment.

\footnotetext{
Thyroid Clinic, Launceston General Hospital, Launceston, Tasmania 7250 Australia

J C STEWART, MB, FRACGP, clinical assistant

G I VIDOR, MB, FRACP, physician
}

These two groups together reflect, but do not represent, the actual incidence of the disease as they take no account of patients who may have been treated only with antithyroid drugs by private practitioners. As there is no way of accurately counting such patients we did not attempt to record them. Discussion with other practitioners, however, suggested that the number was not high and that the proportion of the total was more or less constant throughout the study.

Diagnosis-The diagnosis of thyrotoxicosis in patients in group 1 was based on the usual clinical criteria supported by the results of at least two of the following studies: measurement of chemical protein-bound iodine (PBI), serum thyroxine, serum triiodothyronine (T3), T3 resin uptake, ${ }^{131}$ I uptake, PB ${ }^{131}$ I at 48 hours, or T3 suppression. The diagnosis was confirmed by response to treatment. In the patients treated elsewhere the diagnosis of the doctor in charge was accepted; in most cases the responsible doctor was a past or present member of the thyroid clinic at Launceston General Hospital and biochemical data to support the diagnosis were available so that criteria in the two groups were unlikely to have differed appreciably.

Radioiodine uptakes in euthyroid subjects-These were obtained from the records of the department of nuclear medicine. The subjects had all been investigated because thyroid disease was suspected, but they were all found to be euthyroid. Unfortunately no data exist for 1965-6 as the unreliability of radioiodine uptakes as indicators of thyrotoxicosis in areas of iodine deficiency led to their abandonment when the in-vitro tests (T3 resin uptake, PBI) became available in 1963.

General data-Statistics on food imports to Tasmania and on population were obtained from the Deputy Commonwealth Statistician, Hobart. The data on the prevalence of goitre among schoolchildren were compiled by Clements et al. ${ }^{14}$

\section{Results}

Table I and the figure indicate that the incidence of thyrotoxicosis during 1960-3 was stable. In 1964 and 1965 there was a significant $(P<0.02)$ increase, which was greatest among patients over the age of 40 years, whose number doubled. A second, more dramatic, increase began late in 1966 after the addition of iodine to bread in March of that year. It reached its peak in 1967 and it too was largely caused by an increase in the numbers of patients with thyrotoxicosis among those over the age of 40 . After three years of declining numbers there was, in 1971, a further increase in the number of thyrotoxic patients; although the increase was not statistically significant it represented a reversal of the decline, and patients over 40 years of age were wholly responsible. Since then the incidence has steadily fallen.

High thyroid radioiodine uptakes at four hours in euthyroid subjects (table II) in 1960-3 reflected the prevailing iodine deficiency, and the

TABLE I-Incidence of thyrotoxicosis in northern Tasmania 1960-74 according to whether patients were aged under or over 40

\begin{tabular}{|c|c|c|c|c|c|c|c|c|c|c|c|c|c|c|c|}
\hline$\underset{\text { (years) }}{\text { Age }}$ & 1960 & 61 & 62 & 63 & 64 & 65 & 66 & 67 & 68 & 69 & 70 & 71 & 72 & 73 & 74 \\
\hline $\begin{array}{l}\$ 39 \\
\geqslant 40\end{array}$ & $\begin{array}{l}10 \\
15\end{array}$ & $\begin{array}{l}12 \\
11\end{array}$ & $\begin{array}{r}8 \\
13\end{array}$ & $\begin{array}{r}7 \\
14\end{array}$ & $\begin{array}{l}13 \\
28\end{array}$ & $\begin{array}{l}11 \\
28\end{array}$ & $\begin{array}{l}14 \\
62\end{array}$ & $\begin{array}{l}22 \\
80\end{array}$ & $\begin{array}{l}19 \\
66\end{array}$ & $\begin{array}{l}21 \\
48\end{array}$ & $\begin{array}{l}17 \\
44\end{array}$ & $\begin{array}{l}16 \\
53\end{array}$ & $\begin{array}{l}15 \\
46\end{array}$ & $\begin{array}{l}14 \\
39\end{array}$ & $\begin{array}{l}10 \\
35\end{array}$ \\
\hline Total & 25 & 23 & 21 & 21 & 41 & 39 & 76 & 102 & 85 & 69 & 61 & 69 & 61 & 53 & 45 \\
\hline
\end{tabular}

TABLE II-Thyroid uptake of ${ }^{131} I$ at four hours in euthyroid subjects seen from 1961 to 1972 in Launceston General Hospital

\begin{tabular}{l|r|r|r|r|r|r|r|r|r|r|r|r}
\hline Year: & 1961 & 62 & 63 & 64 & 65 & 66 & 67 & 68 & 69 & 70 & 71 & 72 \\
\hline $\begin{array}{c}\text { No of subjects } \\
\text { Mean 4-h 131I } \\
\text { uptake (\%) }\end{array}$ & 22 & 25 & 15 & 4 & & & 33 & 17 & 19 & 33 & 29 & 38 \\
& 52 & 54 & 47 & 38 & & 18 & 20 & 15 & 17 & 17 & 17 \\
\hline
\end{tabular}


TABLE III-Prevalence of goitre in children in Tasmania from 1949 to 1965 according to age 14

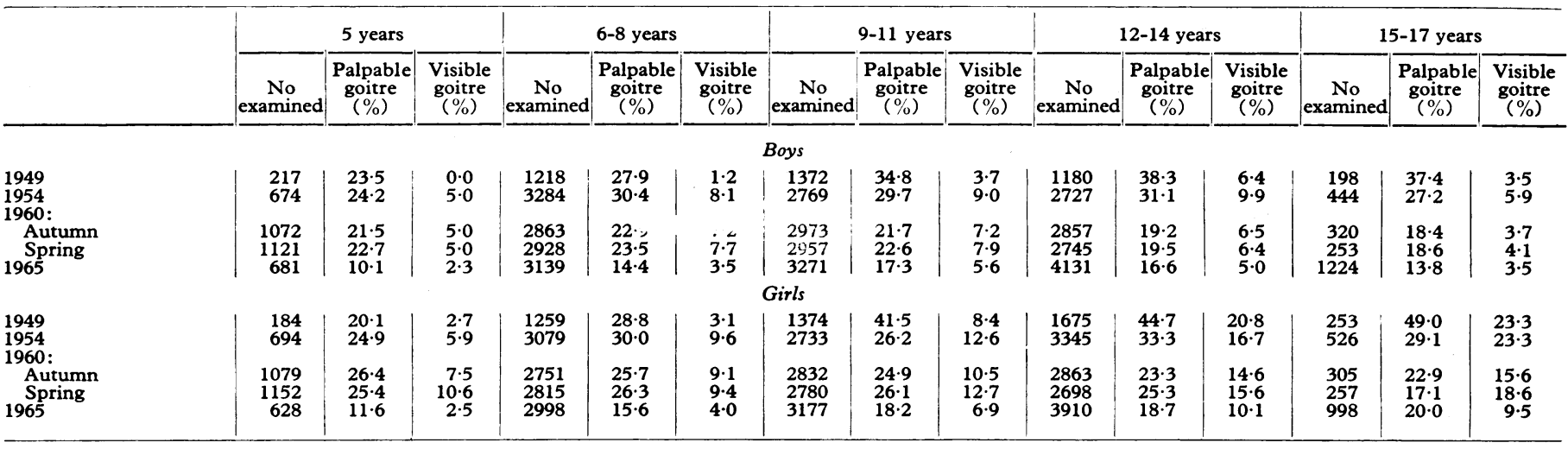

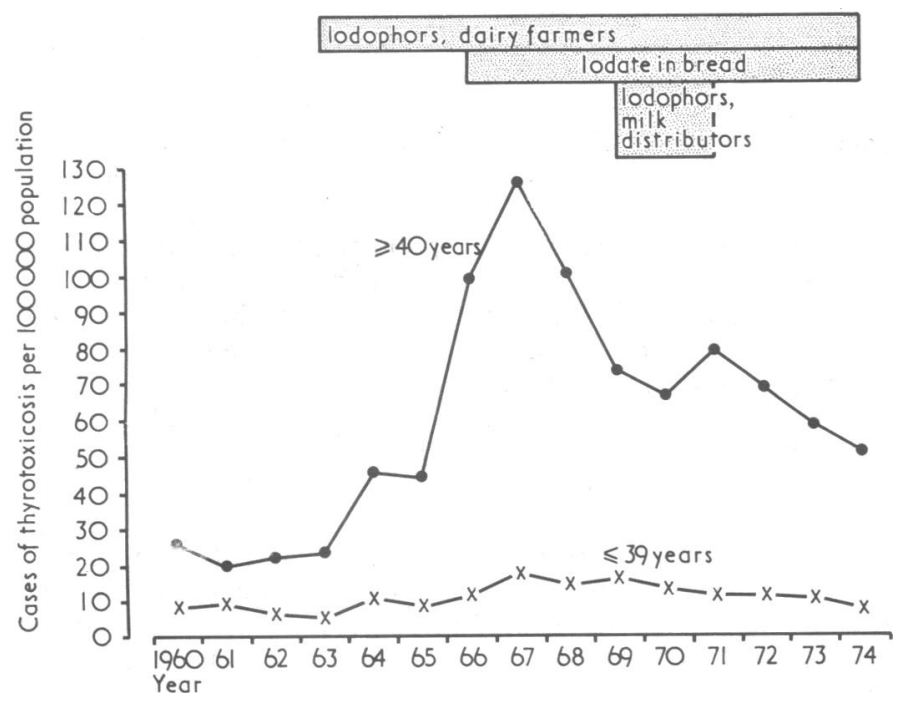

Age-specific incidence of thyrotoxicosis in northern Tasmania 1960-74. Bars indicate duration, but not magnitude, of various factors adding to dietary iodine.

fall after 1966 confirmed its correction. The scanty data for 1964, when only 4 patients were tested, were compatible with an improvement in iodine nutrition at that time.

Table III shows the prevalence of goitre in Tasmanian schoolchildren at roughly five year intervals from 1949 to 1965.14 This survey was carried out to study the effect of the goitre prophylaxis that was carried out from 1950 onwards. Potassium iodide tablets were distributed to schoolchildren, preschool children, and expectant mothers, but in practice few preschool children received the tablets. ${ }^{14}$ In children over the age of nine years there was a steady decline in the prevalence of palpable goitre after the scheme started. In children aged 5-8 years the prevalence of goitre was virtually unchanged from 1949 to 1960 but between 1960 and 1965 it fell by about half.

Freight services between the Australian mainland and Tasmania improved considerably after the introduction of roll-on roll-off ferries in 1959. This led to increased imports of fish, cereal products, and vegetables (table IV).

\section{Discussion}

The data show that since 1960 the incidence of thyrotoxicosis in northern Tasmania has risen appreciably three times and that each time people aged over 40 accounted for most of those affected. This suggests that a common factor may have been responsible. As we know that the increase in 1966 was precipitated by an increase in dietary iodine, caused by the addition of iodate to bread as prophylaxis against goitre. ${ }^{13}$ There is reason to suspect a similar cause for the increases of 1964 and 1971.

Although formal studies of iodine nutrition were carried out in 1965 and 1967 and showed the correction of iodine deficiency by bread iodination in $1966,{ }^{15}$ similar data for the period before 1965 do not exist. Thyroid uptake of radioiodine in euthyroid subjects sheds little light on iodine nutrition in 1964 as the number tested was so small. The most that can be said is that the data are not inconsistent with an improvement in iodine nutrition during 1963-4. Indirect evidence of increasing dietary iodine at this time comes from the goitre surveys in children. As the five-year-old children had received no prophylactic iodide tablets, and the 6-8 year olds had received these for only a short time, changes in the prevalence of goitre in these groups may be taken to reflect changes in the iodine content of the normal Tasmanian diet. In both groups the prevalence of goitre was

TABLE IV-Overseas and interstate imports of foodstuffs into Tasmania 1960-6 (Data provided by Deputy Commonwealth Statistician, Hobart)

\begin{tabular}{|c|c|c|c|c|c|c|c|}
\hline \multirow{2}{*}{ Description } & \multicolumn{7}{|c|}{ Year ended 30 June } \\
\hline & 1960 & 1961 & 1962 & 1963 & 1964 & 1965 & 1966 \\
\hline \multicolumn{8}{|c|}{ Fish and fish preparations } \\
\hline \multirow{3}{*}{$\begin{array}{l}\text { Fresh or frozen (cwt) } \\
\text { Canned and otherwise preserved } \\
\left(1 \mathrm{lb} \times 10^{3}\right)\end{array}$} & 4062 & 5214 & 5503 & 6593 & 8371 & 8281 & 9997 \\
\hline & 622 & 686 & 724 & 899 & 959 & 1016 & 1381 \\
\hline & \multicolumn{7}{|c|}{ Cereal grains } \\
\hline $\begin{array}{l}\text { Wheat (ton) } \\
\text { Rice (ton) } \\
\text { Other (ton) }\end{array}$ & $\begin{array}{r}54252 \\
6215 \\
5597\end{array}$ & $\begin{array}{r}55773 \\
4420 \\
2240\end{array}$ & $\begin{array}{r}47379 \\
3786 \\
2484\end{array}$ & $\begin{array}{r}47041 \\
4231 \\
1075\end{array}$ & $\begin{array}{r}41304 \\
5914 \\
997\end{array}$ & $\begin{array}{r}43778 \\
4819 \\
528\end{array}$ & $\begin{array}{r}49185 \\
4052 \\
607\end{array}$ \\
\hline \multicolumn{8}{|c|}{ Cereal preparations } \\
\hline $\begin{array}{l}\text { Meal and flour of wheat (ton) } \\
\text { Meal and flour of other cereals (ton) } \\
\text { Biscuits and cakes }\left(1 \mathrm{l} \times 10^{3}\right)\end{array}$ & $\begin{array}{r}414 \\
196 \\
1834\end{array}$ & $\begin{array}{r}393 \\
176 \\
1768\end{array}$ & $\begin{array}{r}341 \\
166 \\
1549\end{array}$ & $\begin{array}{r}547 \\
344 \\
2051\end{array}$ & $\begin{array}{r}576 \\
393 \\
2312\end{array}$ & $\begin{array}{r}776 \\
475 \\
1783\end{array}$ & $\begin{array}{r}702 \\
303 \\
2387\end{array}$ \\
\hline \multicolumn{8}{|c|}{ Vegetables } \\
\hline $\begin{array}{l}\text { Fresh or frozen (cwt) } \\
\text { Preserved }\left(\mathrm{lb} \times 10^{3}\right)\end{array}$ & $\begin{array}{r}70758 \\
472\end{array}$ & $\begin{array}{r}136650 \\
368\end{array}$ & $\begin{array}{r}129812 \\
374\end{array}$ & $\begin{array}{r}118818 \\
464\end{array}$ & $\begin{array}{r}151004 \\
609\end{array}$ & $\begin{array}{r}172711 \\
696\end{array}$ & $\begin{array}{r}185617 \\
856\end{array}$ \\
\hline
\end{tabular}

Conversion: traditional to $S I$ units: $1 \mathrm{cwt} \approx 50.8 \mathrm{~kg} . \quad 1 \mathrm{lb} \approx 0.454 \mathrm{~kg} . \quad 1$ ton $=1.016$ tonnes. 
halved between 1960 and 1965, suggesting an appreciable increase in dietary iodine.

The increased importation of food-stuffs produced in iodinesufficient areas of the mainland no doubt contributed to the increase in dietary iodine but cannot explain fully the increase in thyrotoxicosis, as this occurred suddenly in 1964 while imports increased gradually. The most probable explanation of the changes in iodine nutrition and incidence of thyrotoxicosis became apparent with Connolly's important discovery of iodine residues in milk resulting from the use of iodophors in the dairy industry. ${ }^{16}$ These disinfectants, which contain high concentrations of iodine, were introduced into Tasmania during 1963.

Iodophors are widely used in dairies for washing udders and for cleaning milking machines and storage vats. Their use leads to contamination of the milk with varying quantities of iodine. Connolly ${ }^{16}$ reported levels ranging from 890 to $2727 \mathrm{nmol} / \mathrm{l}$ $(11.3$ to $34.6 \mu \mathrm{g} / 100 \mathrm{ml})$ in milk from farms using iodophors compared with a maximum of $181 \mathrm{nmol} / 1(2 \cdot 3 \mu \mathrm{g} / 100 \mathrm{ml})$ where iodophors were not used. We know of a sample of milk containing $7880 \mathrm{nmol} / \mathrm{l}(100 \mu \mathrm{g} / 100 \mathrm{ml})$. Even the lowest concentration of $890 \mathrm{nmol} / \mathrm{l}$ reported by Connolly represents about $4728 \mathrm{nmol}(60 \mu \mathrm{g})$ in a pint of milk. In an iodine-deficient area like Tasmania, where average daily intake in the early 1960s was probably less than $7880 \mathrm{nmol}$ an additional $4728 \mathrm{nmol}$ would represent a substantial change.

Thus the increase in thyrotoxicosis in 1964-5, which showed the age distribution that is associated with iodine-induced thyrotoxicosis, occurred at a time when additional iodine was entering the Tasmanian diet through the use of iodophors and through increased food imports. The falling prevalence of goitre in young children suggests that this extra iodine was enough to have an appreciable effect on the overall state of iodine nutrition. We feel this gives reasonable grounds for believing that this was another example of iodine-induced thyrotoxicosis, the first such occurrence that has been reported in response to a chance increase in dietary iodine.

The increased thyrotoxicosis in 1971 may also have been iodine-induced, for late in 1969 and in 1970 the major milk distributors in Tasmania began to use iodophors in their road tankers, bulk storage vats, and bottling plants. This practice stopped in 1971.

\section{PATHOGENESIS}

These results are of interest in relation to the pathogenesis of iodine-induced thyrotoxicosis. This condition occurs only in people whose thyroid activity is already free of normal hypothalmic-pituitary control because of autonomous nodules or Graves's disease,${ }^{17}$ the former being the more common. ${ }^{18}$ Autonomous thyroid tissue is common in euthyroid people with goitre ${ }^{19}$ and its hormone output is regulated by the availability of iodine ${ }^{7}$ and, presumably, by its mass. From this it might be predicted that in a population with high prevalence of goitre, like that of Tasmania, a small increase in iodine intake would precipitate hyperthyroidism in those possessed of a large mass of autonomous thyroid tissue while larger increases would be required to produce the same effect in those with smaller masses of unregulated tissue. Similar considerations probably apply to the unregulated tissue of subclinical Graves's disease. Thus, successive increases in iodine would cause successive waves of thyrotoxicosis. The events described in this paper are compatible with this having occurred and support our hypothesis.

\section{Implications}

Wider implications are raised by our studies. Except in the most isolated communities iodine nutrition is not constant. Since early times an exchange of foodstuffs has probably occurred between iodine-sufficient and iodine-deficient areas. Modern methods of transport and food preservation have greatly increased this traffic so that in developed societies the average diet is derived from diverse sources. This has no doubt led to spontaneous alleviation of iodine deficiency in many areas. Two recent innovations in food technology have, however, introduced the possibility of massive increases in dietary iodine: the use of iodophors in dairying and the use of iodine-containing additives in "continuous mix" automated bread making. "0-22 The effects of these have been noted in the USA, where milk is described as a major source of iodine, ${ }^{23}$ and bread contains iodine in concentrations up to $21118 \mathrm{nmol}$ per slice. ${ }^{22}$ Falling thyroid radioiodine uptakes ${ }^{21}{ }^{22}$ and increasing urinary iodine excretion ${ }^{23}$ have resulted. These changes in food technology will almost inevitably affect other countries, if they have not already done so, and in areas previously deficient in iodine must introduce the risk of iodine-induced thyrotoxicosis. Even iodine-replete areas are probably not entirely free of such risk for people with goitre are found everywhere, the prevalence of euthyroid Graves's disease is unknown, and iodine deficiency is not a prerequisite for iodine-induced thyrotoxicosis. ${ }^{8}$

Another undesirable effect of increased dietary iodine may be a reduction in the remission rate of Graves's disease after treatment; an inverse relationship between the two has been suggested. ${ }^{24}$ Such a relationship would accord with the concept of iodine's being a determinant of hormone production in unregulated thyroid tissue.

In Tasmania a clearly defined population, the concentration of cases at two thyroid clinics, and a high awareness of thyroid disease created favourable circumstances for the detection of change. Despite this a virtual doubling in the incidence of thyrotoxicosis went unnoticed for three years and iodophors were not recognised as a potent source of dietary iodine until six years after they were first used.

For these reasons we strongly believe that it is the responsibility of public health authorities to monitor iodine nutrition regularly by measurements of urinary iodine excretion or thyroid uptake of radioiodine. Although desirable in all areas it is essential in areas of endemic goitre. Should increases in iodine nutrition be detected then clinicians, both in specialist and general practice, should be alerted to the possibility of iodine-induced thyrotoxicosis occurring. Unless specifically suspected the condition may escape recognition as it mostly affects older patients in whom symptoms may be atypical; is insidious in onset; may present as cardiac failure with minimal other evidence of hyperthyroidism; and may be difficult to detect with standard thyroid function tests, as an appreciable incidence of T3-toxicosis has been found in our clinic (to be published).

The unplanned increases in dietary iodine which we have discussed may well spare public health officials in areas of endemic goitre from the ethical dilemma of whether eliminating goitre by iodine supplementation justifies the risk of iodineinduced thyrotoxicosis. It also, however, poses the question of whether, because of the risk of iodine-induced thyrotoxicosis, the addition of iodine to common foodstuffs should be more severely restricted. We believe that it should. While controlled correction of iodine deficiency remains as desirable as ever the haphazard and massive contamination of food with a physiologically potent element is undesirable and probably dangerous.

Bread and milk have traditionally been regarded as the ultimate in innocuous fare. In the present circumstances it may be that for the goitrous cakes and ale provide safer sustenance.

We thank Mrs C Westmore for performing the statistical analyses, Mr Paul Richards, senior medical nucleographer, for technical services and for drawing the graph, and Mrs Dianne Wells for secretarial services. We thank Dr F W Clements, Dr H B Gibson, and Mrs J F Howeler-Coy and the editor of Bulletin of the World Health Organisation for permission to reproduce table III.

The work was supported by the board of management, Launceston General Hospital, and the Department of Health Services, Tasmania.

\section{References}

${ }^{1}$ Coindet, J F, Annales de Chimie et de Physique, 1820, 15, 40. 
${ }^{2}$ Breuer, R, Wiener klinische Wochenschrift, 1900, 13, 641.

${ }^{3}$ Kocher, T, Deutsche Klinic, 1904, 8, 1115.

${ }^{4}$ Kocher, T, Archiv für klinische Chirurgie, 1910, 92, 1166.

5 Jackson, A S, Boston Medical and Surgical fournal, 1925, 193, 1138.

${ }^{6}$ Ek, B, Johnsson, S, and von Porat, B, Acta Medica Scandinavica, 1963, 173, 341 .

${ }^{7}$ Ermans, A M, and Camus, M, Acta Endocrinologica, 1972, 70, 463.

${ }^{8}$ Vagenakis, A G, et al, New England fournal of Medicine, 1972, 287, 523.

9 Denham, M J, and Himsworth, R L, Age and Ageing, 1974, 3, 221.

${ }_{10}$ Hartsock, C L, fournal of the American Medical Association, 1926, 86, 1334.

${ }_{11}$ McClure, R D, Annals of Surgery, 1927, 85, 333.

12 Van Leeuwen, E, Nederlandsche Tijdschrift Geneesk, 1954, 98, 81.

13 Connolly, R J, Vidor, G I, and Stewart, J C, Lancet, 1970, 1, 500.

${ }_{14}$ Clements, F W, Gibson, H B, and Howeler-Coy, J F, Bulletin of the World Health Organisation, 1968, 38, 297.
15 Stewart, J C, et al, Australian and New Zealand fournal of Medicine, 1971, 3, 203.

${ }^{16}$ Connolly, R J, Medical fournal of Australia, 1971, 1, 1268.

17 Adams, D D, et al, fournal of Clinical Endocrinology and Metabolism, 1975, $41,221$.

18 Vidor, G I, et al, fournal of Clinical Endocrinology and Metabolism, 1973, 37, 901.

${ }^{19}$ Miller, J M, and Block, M A, fournal of the American Medical Association, $1970,214,535$

${ }^{20}$ London, W T, Vought, R L, and Brown, F A, New England fournal of Medicine, 1965, 273, 381.

${ }^{21}$ Pittman, J A, et al, New England fournal of Medicine, 1969, 280, 1431.

22 Sachs, B A, et al, British Medical fournal, 1972, 1, 79.

${ }^{23}$ Kidd, P S, ee al, Fournal of the American Dietetic Association, 1974, 65, 420.

${ }^{24}$ Wartofsky, L, fournal of the American Medical Association, 1973, 226, 1083.

$6 a x$

\section{Secondary ámyloidosis due to Schistosoma mansoni infection

\author{
jelus
}

HASSAN OSMAN OMER,

SADIG MOHAMED/ABDEL - WAHAB

British Medical fournal, 1976, 1, 375-377

\section{Summary}

Four children with Schistosoma mansoni infection and the nephrotic syndrome with varying degrees of renal dysfunction were found on histological examination to have amyloidosis. In one boy who had no evidence of renal failure complete clinical regression of his nephrotic syndrome and almost complete disappearance of renal amyloid deposits followed adequate treatment of his schistosomal infection. Conditions known to cause secondary amyloidosis were excluded in all four patients. Amyloidosis in association with mansoni infection is probably more common than is currently recognised. Early treatment of the infection, before renal function becomes impaired, may result in regression of the amyloidosis.

\section{Introduction}

The skewing of the age incidence of nephrosis in Nigeria with a peak at 8 years lead to the suggestion ${ }^{1}$ that quartan malaria may be a primary cause. This suggestion was later proved by immunopathological studies ${ }^{2}$ that showed deposits of IgM and C3 complexes in glomerular capillary walls. This relation between quartan malaria and nephrosis has led to the suggestion ${ }^{3}$ that similar associations may exist between nephrosis and other infections, especially schistosomiasis. In areas where schistosomiasis is common and where the age incidence of nephrosis is similar to that identified in Nigeria comparable mechanisms relating schistosomiasis to nephrosis would be expected. Work from South America ${ }^{4}{ }^{5}$ has shown a uniform pattern of kidney lesions in patients with hepatosplenic schistosomiasis. In these studies focal electron-dense deposits were seen that corresponded to $\gamma$-globulin and complement as shown by immunofluorescence

Faculty of Medicine, University of Khartoum, Khartoum, Sudan

HASSAN OSMAN OMER, MRCP, DCH, head of department of paediatrics and child health

SADIG MOHAMED ABDEL WAHAB, DPATH, MRCPATH, lecturer, department of pathology microscopy, but no cases of amyloidosis were described. We have recently examined seven children with schistosomiasis and renal disease.

\section{Patients and methods}

In the first patient with schistosomiasis and nephrosis amyloidosis was suspected on clinical grounds, so a specific stain for amyloid was used on biopsy material. Six more children with Schistosoma mansoni infection and the nephrotic syndrome or renal dysfunction, or both, were subsequently seen. Two died soon after admission and permission for necropsy was refused, and in one patient it was impossible to perform a renal biopsy. The remaining three children and the first patient are the subject of this report.

In all four chest $x$-ray and skeletal surveys showed nothing abnormal. Lupus erythematosus cell preparation, rheumatoid factor, and Kahn and Wasserman reaction test results were negative. Haemoglobin electrophoresis showed Hb AA in all four patients. Cerebrospinal fluid was normal and there was no clinical indication of leprosy. In all patients the diagnosis of amyloid was based on Congo-red staining and birefringence to polarised light.

\section{Case 1}

A 10-year-old boy was admitted on 10 May 1974 with a five-month history of progressive ascites and generalised oedema. Examination showed gross anasarca, blood pressure of $120 / 80 \mathrm{~mm} \mathrm{Hg}$, and hepatomegaly to $7 \mathrm{~cm}$ below the right costal margin, with prominent enlargement of the left lobe with a smooth and firm surface. The spleen was palpable $6 \mathrm{~cm}$ below the left costal margin. Haemoglobin was $9.5 \mathrm{~g} / \mathrm{dl}$, packed cell volume $31 \%$, total plasma proteins $53 \mathrm{~g} / \mathrm{l}$, albumin $27 \mathrm{~g} / 1$, serum cholesterol $7.5 \mathrm{mmol} / 1(290 \mathrm{mg} / 100 \mathrm{ml})$, blood urea $5 \cdot 2 \mathrm{mmol} / 1(31 \mathrm{mg} / 100 \mathrm{ml})$, and 24-hour urinary protein excretion $6 \cdot 3 \mathrm{~g}$. Stool examination showed no parasites. Treatment with a high protein diet and diuretics was started. Liver biopsy on 6 June 1974 showed several schistosomal granulomata and extensive amyloid deposits. Subsequently proctoscopy and examination of a rectal snip showed viable schistosoma ova. Percutaneous renal biopsy showed extensive amyloid deposits (figs 1 and 2 ) in all glomeruli and in tubular basement membrane and artery walls. His schistosomiasis was treated with a single injection of hycanthone (Etrenol).

After three months 24-hour urinary protein fell to $0 \cdot 15 \mathrm{~g}$. There was no oedema, the liver was just palpable on deep inspiration, and the spleen could not be palpated. Haemoglobin was $10 \cdot 1 \mathrm{~g} / \mathrm{dl}$, total plasma protein $72 \mathrm{~g} / \mathrm{l}$, albumin $40 \mathrm{~g} / \mathrm{l}$, serum cholesterol $5 \cdot 1 \mathrm{mmol} / 1$ (195 $\mathrm{mg} / 100 \mathrm{ml}$ ), and blood urea $4.0 \mathrm{mmol} / 1(24 \mathrm{mg} / 100 \mathrm{ml})$. Liver biopsy showed that amyloid deposits had almost completely disappeared, and renal deposits had regressed considerably. Six months after 